\title{
Kemunduran Benih Kedelai Akibat Pengusangan Cepat Menggunakan Alat IPB 77-1 MM dan Penyimpanan Alami
}

\author{
Soybean Seed Deterioration Using Accelerated Aging Machine IPB 77-1 MM Compared to \\ Natural Storage
}

\author{
Syarifa Mustika, M Rahmad Suhartanto*, Abdul Qadir \\ Departemen Agronomi dan Hortikultura, Fakultas Pertanian, Institut Pertanian Bogor \\ (Bogor Agricultural University), Jl. Meranti, Kampus IPB Darmaga, Bogor 16680, Indonesia \\ Telp.\&Faks. 62-251-8629353 e-mail agronipb@indo.net.id \\ "Penulis untuk korespondensi: otnat@yahoo.com
}

Disetujui 24 Desember 2013/ Published online 13 Februari 2014

\begin{abstract}
Seed deterioration characterized by decrease in viability, vigor and an increase in free fatty. This research was conducted to determine the comformity of the decrease in viability, vigor and an increase in free fatty acids of soybean seed of varieties Anjasmoro and Wilis has aging using accelerated aging machine IPB 77-1 MM compared to natural storage and to determine correlation between viability and vigor compared to free fatty acids. The research consisted of two experiments the natural storage and accelerated aging. Natural storage consists of 5 of storage periods of 0, 2, 4, 6, 8 weeks while accelerated aging consists of 5 of aging periods of $0,15,30,45,60$ minutes. The result showed that the conformity (significant) decrease in viability and vigor between natural storage for 8 weeks compared to accelerated aging for 60 minutes, while in free fatty acids absence of conformity (not significant) between natural storage for 8 weeks (assumed after natural storage for 8 weeks will be increase free fatty acids) compared to accelerated aging for 30 minutes (Anjasmoro) and 15 minutes (Wilis). Viability and vigor compared to free fatty acids had negative correlation, it means increase in free fatty acids effect to decrease in viability and vigor.
\end{abstract}

Key word: free fatty acid, viability, vigor

\section{ABSTRAK}

Kemunduran benih ditandai dengan penurunan vigor, viabilitas, dan peningkatan asam lemak bebas. Penelitian ini bertujuan untuk mengetahui kesesuaian penurunan viabilitas, vigor dan peningkatan asam lemak bebas benih kedelai Varietas Anjasmoro dan Wilis antara benih yang telah diusangkan menggunakan Alat Pengusangan Cepat (APC) IPB 77-1 MM dengan penyimpanan alami dan untuk mengetahui hubungan antara viabilitas dan vigor dengan asam lemak bebas. Penelitian terdiri atas dua percobaan yaitu penyimpanan alami dan pengusangan. Penyimpanan alami terdiri atas 5 waktu penyimpanan yaitu 0, 2, 4, 6, 8 minggu dan pengusangan terdiri atas 5 waktu pengusangan 0, 15, 30, 45, 60 menit. Hasil menunjukkan bahwa adanya kesesuaian (korelasi nyata) laju penurunan viabilitas dan vigor antara penyimpanan alami selama 8 minggu dengan pengusangan selama 60 menit, sedangkan pada asam lemak bebas tidak adanya kesesuaian (korelasi tidak nyata) antara penyimpanan alami selama 8 minggu (diasumsikan setelah penyimpanan selama 8 minggu terjadi peningkatan asam lemak bebas) dengan pengusangan selama 30 menit (Anjasmoro) dan 15 menit (Wilis). Viabilitas dan vigor dengan asam lemak bebas berkorelasi negatif, artinya semakin tinggi asam lemak bebas maka viabilitas dan vigor semakin rendah.

Kata kunci: asam lemak bebas, viabilitas, vigor 


\section{PENDAHULUAN}

Kedelai (Glycine $\max (\mathrm{L}$.$) ) merupakan$ salah satu tanaman kacang-kacangan yang sangat penting di Indonesia, karena merupakan bahan dasar makanan dan sumber utama protein nabati. Ketergantungan terhadap kedelai impor sangat memprihatinkan, karena tingginya kebutuhan dalam negeri yang tidak sesuai dengan produktivitas yang rendah. Kebutuhan kedelai setiap tahunnya rata-rata sebesar 2.4 juta ton sedangkan produksi kedelai pada tahun 2011 sebesar 850 ribu ton (BPS 2011).

Salah satu permasalahan yang dihadapi dalam penyediaan benih bemutu adalah penyimpanan benih. Benih yang disimpan mengalami kemunduran mutu benih yang ditandai dengan penurunan vigor maupun viabilitas benih selama disimpan. Salah satu faktor pembatas produksi kedelai di daerah tropis adalah cepatnya kemunduran mutu benih selama penyimpanan hingga mengurangi penyediaan benih berkualitas tinggi (Purwanti 2004). Menurut Justice dan Bass (2002) setiap benih memiliki laju kemunduran yang berbeda tergantung pengaruh genetik, dormansi benih, ketebalan, dan struktur kulit serta komposisi kimia dalam benih.

Pengujian viabilas benih berdasarkan pendekatan fisiologis salah satunya yaitu metode pengusangan cepat. Metode pengusangan cepat dilakukan untuk mempercepat kemunduran benih. Kemunduran benih dipercepat dengan perlakuan pada kondisi suboptimum yaitu penderaan terhadap benih agar sesuai dengan kondisi simpan yang sebenarnya seperti suhu dan kelembaban udara tinggi, sehingga terjadi devigorasi benih yaitu penurunan viabilitas benih secara buatan. Penelitian Imaniar (2012) menunjukkan bahwa adanya korelasi negatif antara waktu pengusangan cepat dengan parameter viabilitas dan vigor benih, artinya semakin lama waktu pengusangan maka viabilitas dan vigor benih akan semakin rendah yang menandakan benih mengalami kemunduran dan menyatakan bahwa metode pengusangan fisik lebih konsisten dalam hasil pengusangan dilihat dari konsistensi nilai vigor yang dihasilkan pada tolak ukur yang diamati.

Menurut Tatipata et al. (2004) benih kedelai mengalami kemunduran dalam penyimpanan, disebabkan oleh kandungan lemak dan proteinnya yang relatif tinggi sehingga perlu ditangani sebelum disimpan. Kedelai memiliki kadar protein yang tinggi, yaitu sebesar $37 \%$. Selain protein, benih kedelai juga mengandung lemak cukup tinggi, yaitu sebesar $16 \%$.
Kandungan protein dan lemak yang tinggi menyebabkan benih kedelai mengalami kemunduran terutama jika kondisi lingkungan simpan kurang menguntungkan (sub optimum). Menurut Copeland dan McDonald (2001) salah satu gejala dari mutu kemunduran benih adalah peningkatan asam lemak bebas. Peningkatan asam lemak bebas terjadi karena hidrolisis fosfolipid menyebabkan pelepasan gliserol dan asam lemak, dan reaksi ini dipercepat dengan meningkatnya kelembaban benih. Menurut Ketaren (1986) asam lemak bebas diperoleh dari proses hidrolisa yaitu penguraian lemak atau trigliserida oleh molekul air yang menghasilkan asam lemak bebas dan gliserol. Asam lemak bebas terbentuk karena proses oksidasi dan hidrolisa enzim selama pengolahan dan penyimpanan.

Penelitian ini bertujuan untuk mengetahui kesesuaian penurunan viabilitas, penurunan vigor dan peningkatan asam lemak bebas benih kedelai Varietas Anjasmoro dan Wilis antara benih yang telah diusangkan menggunakan Alat Pengusangan (APC) IPB 77-1 MM dengan penyimpanan alami dan untuk mengetahui hubungan antara viabilitas dan vigor dengan asam lemak bebas.

\section{BAHAN DAN METODE}

Penelitian ini dilaksanakan di Laboratorium Ilmu dan Teknologi Benih dan Laboratorium Analisis Tanaman dan Kromatografi, Fakultas Pertanian, Institut Pertanian Bogor pada bulan April hingga Juni 2013. Bahan yang digunakan adalah benih kedelai varietas Anjasmoro dan Wilis yang berasal dari Balai Besar Penelitian Kacang-kacangan dan Umbi-umbian Malang, kertas buram, label, plastik, plastik polipropilen (PP), larutan etanol, larutan kloroform dan larutan PP. Alat yang digunakan yaitu Alat Pengusangan (APC) IPB 77-1 MM, alat pengecambah benih tipe IPB 72-1, alat pengepres kertas tipe IPB 75-1, sealer, timbangan, desikator, oven, cawan, thermohigrometer, handsprayer dan keranjang plastik.

Penelitian ini dilakukan menggunakan dua percobaan yaitu percobaan I, pengusangan cepat secara fisik dengan menggunakan penderaan uap panas pada APC IPB 77-1 MM dan percobaan II, penyimpanan benih secara alami pada suhu kamar.

Percobaan I yaitu pengusangan cepat secara fisik, dilakukan pengusangan pada dua varietas kedelai (Anjasmoro dan Wilis) menggunakan APC IPB 77-1 MM dengan waktu pengusangan yaitu $0,15,30,45$ dan 60 menit dengan tiga ulangan. Pengusangan cepat dengan 
APC IPB 77-1 MM dilakukan dengan uap panas yang berasal dari proses pemanasan air sebanyak 4 liter yang terdapat dalam panci yang dididihkan dengan kompor listrik selama 2 jam dan menunggu uap panas masuk keruang pengusangan hingga suhu dan kelembaban ruang pengusangan menjadi $45-50^{\circ}$ dan $87-90 \%$ (30 menit). Benih dimasukkan kedalam tabung-tabung pengusangan lalu dimasukkan kedalam ruang pengusangan dan proses pengusangan dimulai dan perlu dilakukan buka tutup kran pembuangan uap panas apabila suhu dan kelembaban dalam ruang pengusangan diluar batas yang diinginkan.

Percobaan II yaitu penyimpanan alami, dilakukan penyimpanan alami pada dua varietas kedelai (Anjasmoro dan Wilis) dengan waktu penyimpanan yaitu $0,2,4,6$ dan 8 minggu dengan masing-masing diulang sebanyak tiga kali. Benih kedelai dikemas menggunakan plastik PP dan dipress menggunakan sealer lalu benih dimasukkan ke keranjang plastik dan disimpan dengan kondisi suhu kamar yaitu $26-30^{\circ} \mathrm{C}$ dan RH $60-70 \%$. Parameter yang diamati percobaan I dan II yaitu daya berkecambah (DB), indeks vigor (IV), kadar air (KA) dan asam lemak bebas (ALB).

Penelitian ini menggunakan analisis regresi dan korelasi. Analisis regresi bertujuan untuk mengetahui dan membandingkan hubungan berbagai peubah viabilitas, vigor, dan asam lemak bebas antara benih setelah diusangkan dengan benih selama penyimpanan alami. Analisis korelasi (r) digunakan untuk melihat seberapa besar peubah (y) dapat dipengaruhi oleh peubah (x) dan melihat keeratan hubungannya. Nilai koefisien korelasi yang mendekati $1(\mathrm{r} \approx 1)$ menggambarkan adanya korelasi atau keeratan hubungan. Nilai koefisien determinasi $\left(\mathrm{R}^{2}\right)$ digunakan untuk melihat seberapa besar keragaman peubah (y) dapat digambarkan oleh peubah (x). Nilai $\mathrm{R}^{2}$ yang tinggi menunjukkan hubungan yang erat secara kuantitatif antara peubah tersebut.

\section{HASIL DAN PEMBAHASAN}

\section{Hubungan antara Kadar Air Benih Penyimpanan Alami dengan Pengusangan}

Menurut Kuswanto (2003) kadar air benih merupakan salah satu faktor yang sangat mempengaruhi daya simpan benih. Kadar air benih yang tinggi selama penyimpanan dapat menimbulkan beberapa akibat antara lain: meningkatkan laju respirasi benih dan akan meningkatkan suhu. Peningkatan suhu tersebut menyebabkan enzim antioksidan aktif, sehingga akan merombak cadangan makanan. Kadar air benih sangat dipengaruhi oleh kondisi kelembaban ruang tempat penyimpanan benih, karena sifat benih yang higroskopis, padahal kadar air benih sangat mempengaruhi laju deteriorasi benih.

Hasil analisis regresi antara kadar air benih selama penyimpanan alami dengan kadar air benih setelah pengusangan menunjukkan bahwa nilai koefisien determinasi $\left(\mathrm{R}^{2}\right)$ benih kedelai varietas Anjasmoro sebesar $80 \%$ (> 80\%), artinya $80 \%$ dari keragaman kadar air penyimpanan (y) dapat digambarkan oleh keragaman kadar air pengusangan $(\mathrm{x})$. Nilai koefisien determinasi $\left(\mathrm{R}^{2}\right)$ benih kedelai varietas Wilis sebesar 82\% (> 80\%), artinya $82 \%$ dari keragaman kadar air penyimpanan (y) dapat digambarkan oleh keragaman kadar air pengusangan (x). Hasil analisis regresi antara kadar air benih selama penyimpanan alami dengan kadar air benih setelah pengusangan menunjukkan bahwa nilai koefisien korelasi (r) benih kedelai varietas Anjasmoro sebesar 0.89 (> 0.80) dan berkorelasi nyata. Nilai koefisien korelasi (r) benih kedelai varietas Wilis sebesar $0.90(>0.80)$ dan berkorelasi nyata. Nilai $r$ yang mendekati $1(\mathrm{r} \approx 1)$ menunjukkan hubungan yang sangat erat antara kadar air penyimpanan dengan kadar air pengusangan (Gambar 1).

Hubungan kadar air penyimpanan dengan pengusangan benih kedelai varietas Anjasmoro dan Wilis memiliki nilai korelasi yang nyata sehingga terdapat adanya kesesuaian peningkatan kadar air antara penyimpanan dengan pengusangan. Nilai $R^{2}>80 \%$ sehingga dapat dikatakan bahwa dengan pengusangan dapat menduga kadar air pengusangan.

Peningkatan kadar air benih setelah pengusangan maupun selama penyimpanan alami terjadi dikarenakan benih bersifat higroskopis sehingga dapat menyerap air dari udara sekitar. Pada proses pengusangan benih menyerap uap panas dari lingkungan (ruang pengusangan) sehingga dapat meningkatkan kadar airnya. Peningkatan kadar air pada pengusangan lebih cepat dari penyimpanan alami karena suhu dan kelembaban pada ruang pengusangan $\left(45-50^{\circ} \mathrm{C}\right.$ dan $\mathrm{RH}$ 87-90\%) lebih tinggi dari penyimpanan alami $\left(26-30^{\circ} \mathrm{C}\right.$ dan RH $\left.60-70 \%\right)$. Kadar air awal pada penyimpanan sekitar $7.44 \%$ dan pengusangan sekitar 22.50\% (Anjasmoro) dan kadar air penyimpanan $7.65 \%$ dan pengusangan $22.90 \%$ (Wilis), kadar air awal pengusangan lebih tinggi dari kadar air awal penyimpanan alami karena benih sebelum diusangkan dilembabkan terlebih dahulu dengan kertas buram selama \pm 11 jam. 
Pelembaban dilakukan agar benih mengalami imbibisi yang dapat memudahkan uap panas

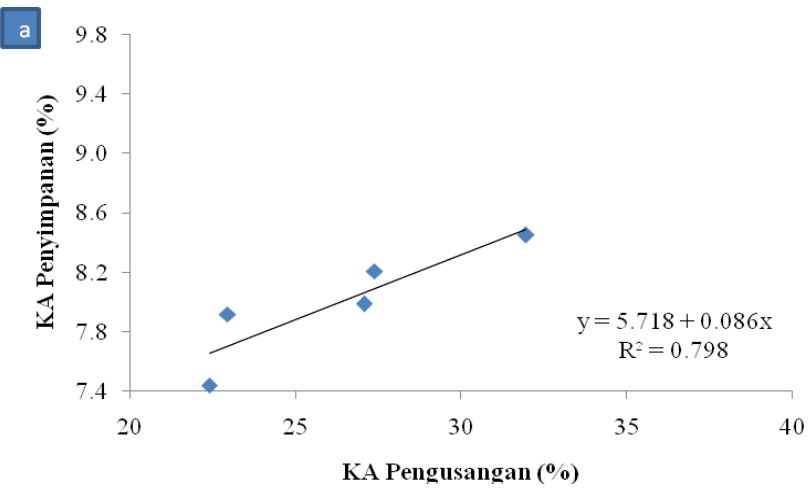

Gambar 1. Hubungan antara KA penyimpanan alami dan KA pengusangan benih kedelai varietas Anjasmoro (a) dan Wilis (b)

Daya Berkecambah Benih selama Waktu Penyimpanan Alami dan Waktu Pengusangan

Hasil analisis regresi antara waktu penyimpanan alami dengan daya berkecambah kedelai varietas Anjasmoro dan Wilis hasilnya menunjukkan bahwa terjadi korelasi yang negatif. Korelasi negatif menunjukkan hubungan yang berbanding terbalik, artinya semakin lama waktu penyimpanan alami maka daya berkecambah juga semakin rendah, begitu pun yang terjadi antara waktu pengusangan dengan daya berkecambah yaitu terjadi korelasi yang negatif. Laju penurunan daya berkecambah benih yang telah diusangkan lebih cepat dibandingkan laju penurunan daya berkecambah benih dengan penyimpanan alami. masuk ke dalam benih selama proses pengusangan.

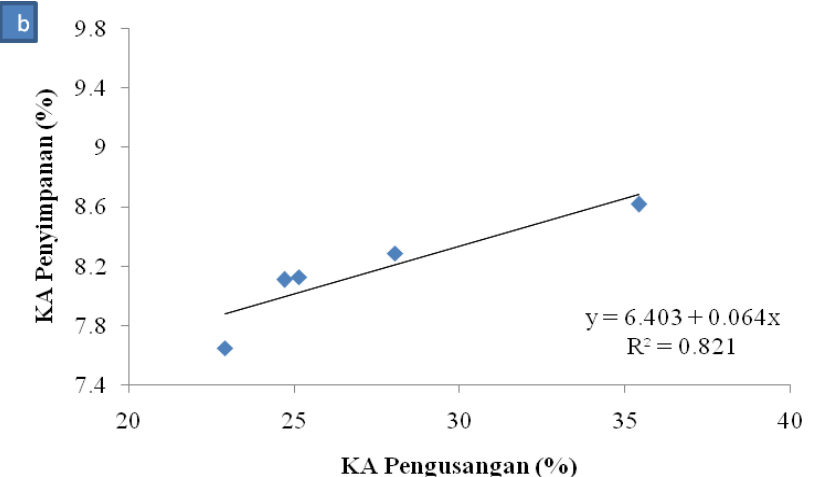

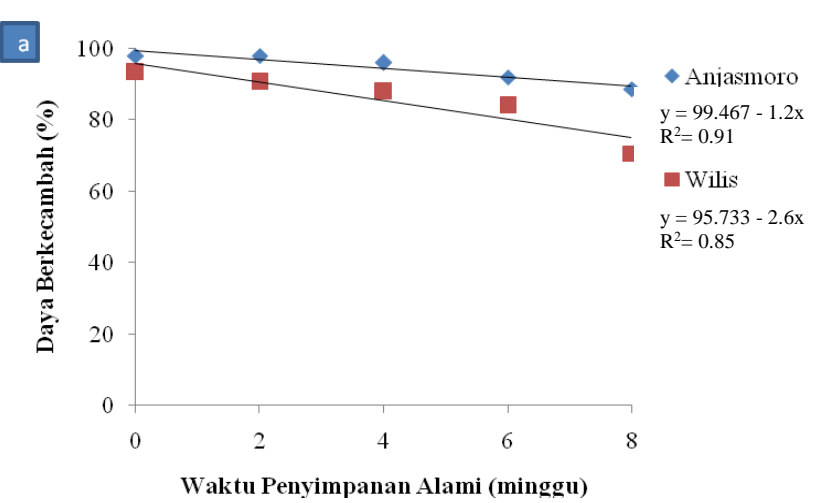

Gambar 2. Hubungan antara waktu penyimpanan alami dengan daya berkecambah (a) dan waktu pengusangan dengan daya berkecambah (b) pada benih kedelai varietas Anjasmoro dan Wilis

Indeks Vigor Benih Selama Waktu Penyimpanan Alami dan Pengusangan

Hasil analisis regresi antara waktu penyimpanan alami dengan indeks vigor benih

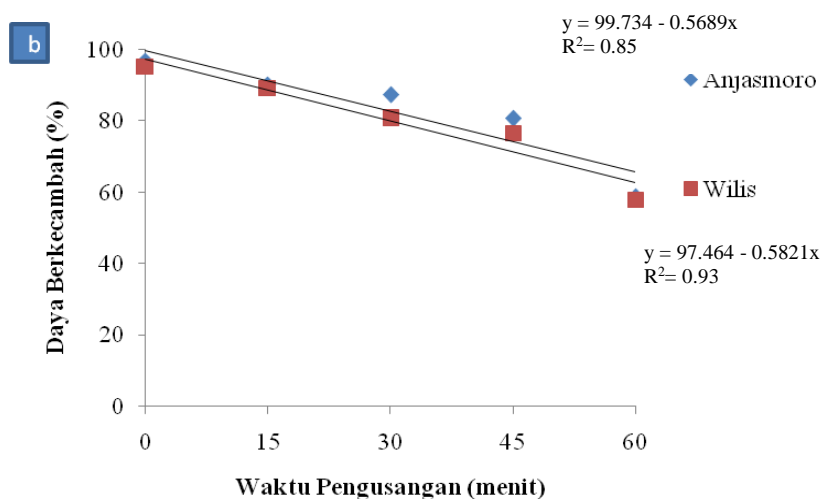

Nilai korelasi (r) antara daya berkecambah dengan waktu penyimpanan alami kedelai varietas Anjasmoro yaitu sebesar 0.95 dan varietas Wilis sebesar 0.92, artinya peubah daya berkecambah (y) dipengaruhi oleh penyimpanan alami $(\mathrm{x})$ sebesar $95 \%$ dan $92 \%$. Nilai korelasi antara daya berkecambah dengan waktu pengusangan kedelai varietas Anjasmoro yaitu sebesar 0.92 dan varietas Wilis 0.96 , artinya peubah daya berkecambah (y) dipengaruhi oleh waktu pengusangan $(\mathrm{x})$ sebesar $92 \%$ dan $96 \%$. Nilai $\mathrm{r}$ yang mendekati $1(\mathrm{r} \approx 1)$ menunjukkan hubungan yang sangat erat antara daya berkecambah dengan waktu penyimpanan alami dan antara daya berkecambah dengan waktu pengusangan (Gambar 2).

kedelai varietas Anjasmoro dan Wilis menunjukkan bahwa terjadi korelasi yang negatif, artinya semakin lama waktu penyimpanan benih secara alami maka indeks vigor benih semakin menurun, begitu pun yang terjadi antara waktu pengusangan dengan indeks vigor yaitu terjadi 
korelasi yang negatif. Laju penurunan indeks vigor benih yang telah diusangkan lebih cepat dibandingkan laju penurunan indeks vigor benih dengan penyimpanan alami.

Nilai korelasi (r) antara waktu penyimpanan alami dengan indeks vigor kedelai varietas Anjasmoro yaitu sebesar 0.99 dan varietas Wilis sebesar 0.98 , artinya peubah indeks vigor (y) dipengaruhi oleh penyimpanan alami $(\mathrm{x})$ sebesar $99 \%$ dan $98 \%$. Nilai korelasi waktu pengusangan dengan indeks vigor kedelai varietas Anjasmoro yaitu sebesar 0.88 dan varietas Wilis sebesar 0.97, artinya peubah indeks vigor (y) dipengaruhi oleh waktu pengusangan (x) sebesar $88 \%$ dan $97 \%$. Nilai $\mathrm{r}$ yang mendekati $1(\mathrm{r} \approx 1)$ menunjukkan hubungan yang sangat erat antara indeks vigor dengan waktu penyimpanan alami dan antara indeks vigor dengan waktu pengusangan (Gambar $3)$.
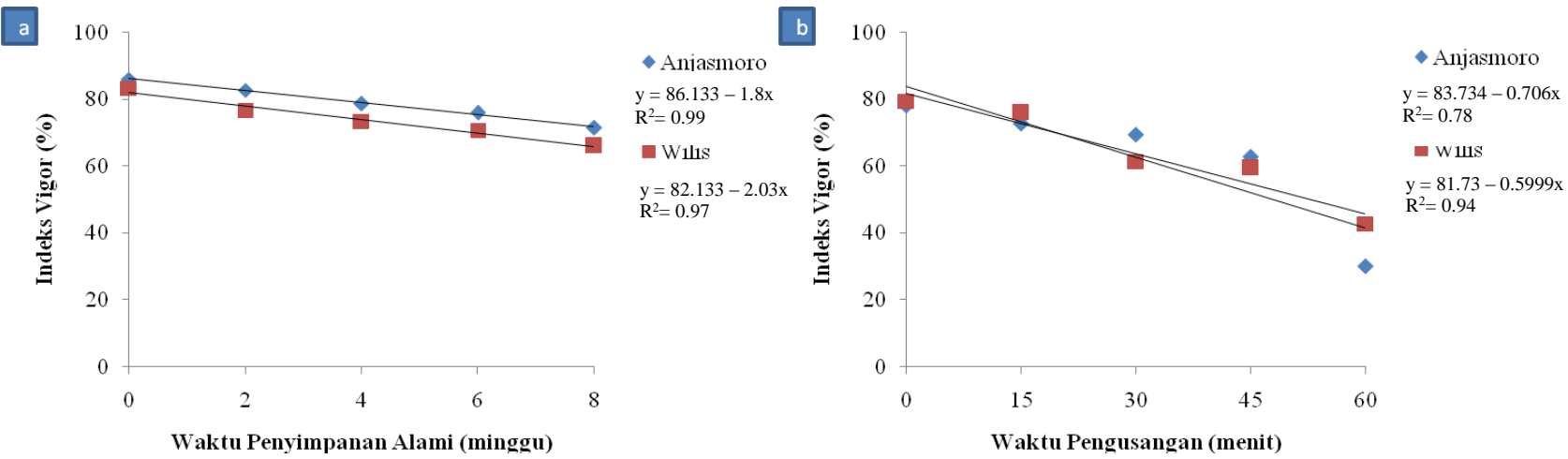

Gambar 3. Hubungan antara penyimpanan alami dengan indeks vigor (a) dan waktu pengusangan dengan indeks vigor (b) pada benih kedelai varietas Anjasmoro dan Wilis

Hubungan Viabilitas dan Vigor Benih antara Penyimpanan Alami dengan Pengusangan

Hasil analisis regresi antara daya berkecambah benih selama penyimpanan dan daya berkecambah benih setelah pengusangan menunjukkan bahwa nilai koefisien determinasi $\left(\mathrm{R}^{2}\right)$ kedelai varietas Anjasmoro sebesar 90\% (> $80 \%$ ), artinya $90 \%$ dari keragaman daya berkecambah penyimpanan (y) dapat digambarkan oleh keragaman daya berkecambah pengusangan (x). Nilai koefisien determinasi $\left(\mathrm{R}^{2}\right)$ kedelai varietas Wilis sebesar 97\% (> 80\%), artinya $97 \%$ dari keragaman daya berkecambah penyimpanan (y) dapat digambarkan oleh keragaman daya berkecambah pengusangan (x). Hasil analisis regresi antara daya berkecambah benih selama penyimpanan dan daya berkecambah benih setelah pengusangan menunjukkan bahwa nilai koefisien korelasi (r) kedelai varietas Anjasmoro sebesar 0.95 (> 0.80) memiliki korelasi nyata dan varietas Wilis sebesar 0.98 (> 0.80 ) memiliki korelasi nyata. Nilai $\mathrm{r}$ yang mendekati $1(\mathrm{r} \approx 1)$ menunjukkan hubungan yang sangat erat antara daya berkecambah penyimpanan dengan pengusangan.

Hubungan antara daya berkecambah penyimpanan dengan pengusangan benih kedelai varietas Anjasmoro dan Wilis memiliki nilai korelasi yang nyata sehingga terdapat adanya kesesuaian penurunan daya berkecambah antara penyimpanan dengan pengusangan. Nilai $R^{2}>80 \%$ sehingga dapat dikatakan bahwa dengan pengusangan dapat menduga daya berkecambah pengusangan (Tabel 1).

Hasil analisis regresi antara indeks vigor benih selama penyimpanan dan indeks vigor benih setelah pengusangan menunjukkan bahwa nilai koefisien determinasi $\left(\mathrm{R}^{2}\right)$ kedelai varietas Anjasmoro sebesar $81 \%$ (> 80\%), artinya $81 \%$ dari keragaman daya berkecambah penyimpanan (y) dapat digambarkan oleh keragaman daya berkecambah pengusangan (x). Nilai koefisien determinasi $\left(\mathrm{R}^{2}\right)$ kedelai varietas Wilis sebesar 90\% (> 80\%), artinya 90\% dari keragaman daya berkecambah penyimpanan (y) dapat digambarkan oleh keragaman daya berkecambah pengusangan (x). Hasil analisis regresi antara indeks vigor benih selama penyimpanan dan indeks vigor benih setelah pengusangan menunjukkan bahwa nilai koefisien korelasi (r) kedelai varietas Anjasmoro sebesar $0.90(>0.80)$ memiliki korelasi nyata dan varietas Wilis sebesar 0.95 (> 0.80$)$ memiliki korelasi nyata. Nilai $\mathrm{r}$ yang mendekati $1(\mathrm{r} \approx 1)$ menunjukkan hubungan yang sangat erat antara indeks vigor penyimpanan dengan pengusangan.

Hubungan antara indeks vigor penyimpanan dengan pengusangan benih kedelai 
varietas Anjasmoro dan Wilis memiliki nilai korelasi yang nyata sehingga terdapat adanya kesesuaian penurunan indeks vigor antara penyimpanan dengan pengusangan. Nilai $\mathrm{R}^{2}>80 \%$ sehingga dapat dikatakan bahwa dengan pengusangan dapat menduga indeks vigor pengusangan (Tabel 1).

Tabel 1. Hubungan daya berkecambah dan indeks vigor antara penyimpanan alami dengan pengusangan

\begin{tabular}{llll}
\hline Hubungan penyimpanan x pengusangan & persamaan regresi & $\mathrm{R}^{2}$ & $\mathrm{r}$ \\
\hline \multicolumn{1}{c}{ Varietas Anjasmoro } & & & \\
DB penyimpanan x DB pengusangan & $\mathrm{y}=-237.01+3.3816 \mathrm{x}$ & 0.90 & $0.95^{*}$ \\
IV penyimpanan x IV pengusangan & $\mathrm{y}=-174.99+3.0091 \mathrm{x}$ & 0.81 & $0.90^{*}$ \\
\hline \multicolumn{1}{c}{ Varietas Wilis } & $\mathrm{y}=-55.18+1.5841 \mathrm{x}$ & 0.97 & $0.98^{* *}$ \\
DB penyimpanan x DB pengusangan & $\mathrm{y}=-94.57+2.1392 \mathrm{x}$ & 0.90 & $0.95^{*}$ \\
IV penyimpanan x IV pengusangan & & &
\end{tabular}

${ }^{a}$ Angka yang diikuti (*) nyata pada taraf 5\% dan (**) sangat nyata pada taraf $1 \%$

Hubungan Asam Lemak Bebas antara Penyimpanan Alami dan Pengusangan

\section{Kandungan Asam Lemak Bebas Selama} Penyimpanan Alami dan Pengusangan

Hasil analisis regresi antara waktu penyimpanan alami dengan asam lemak bebas pada benih kedelai verietas Anjasmoro dan Wilis menunjukkan bahwa terjadi korelasi yang positif. Korelasi positif yang terjadi antara kedua peubah tersebut menunjukkan hubungan yang berbanding lurus, artinya semakin lama penyimpanan benih secara alami maka asam lemak bebas semakin meningkat. Benih kedelai varietas Anjasmoro dan Wilis pada penyimpanan alami terjadi peningkatan asam lemak bebas tetapi tidak signifikan dan memiliki nilai koefisien b untuk kedelai varietas Anjasmoro sebesar 0.0087 dan Wilis sebesar 0.0119, setelah uji statistik hasil menunjukkan bahwa nilai asam lemak bebas pada penyimpanan alami tidak berbeda nyata dengan 0 minggu pada seluruh waktu penyimpanan alami. Nilai korelasi (r) kedelai varietas Anjasmoro sebesar $41 \%$ dan Wilis sebesar $79 \%$. Nilai $r$ yang mendekati $1(r \approx$ 1) menunjukkan keeratan hubungan antara peubah tersebut. Nilai korelasi antara waktu penyimpanan alami dengan asam lemak bebas pada varietas Anjasmoro maupun Wilis menunjukkan nilai korelasi yang tidak nyata (Gambar 4).
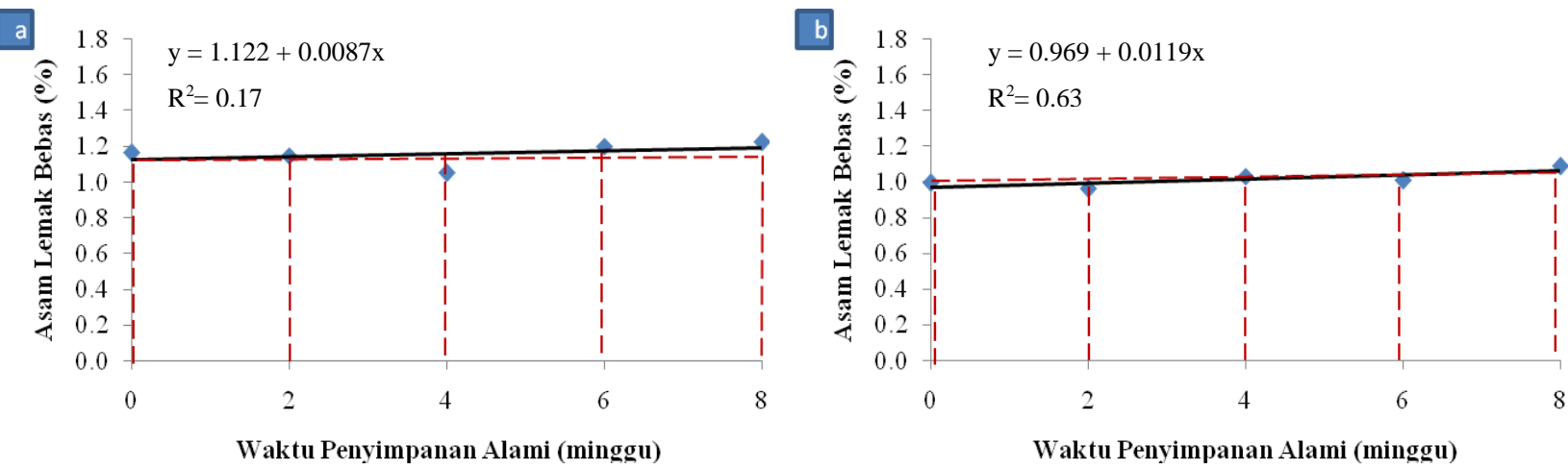

Gambar 4. Hubungan antara waktu penyimpanan alami dengan asam lemak bebas benih kedelai varietas Anjasmoro (a) dan Wilis (b)

Hasil analisis regresi antara waktu pengusangan dan asam lemak bebas benih kedelai varietas Anjasmoro dan Wilis menunjukkan bahwa terjadi korelasi yang positif, artinya semakin lama benih diusangkan maka asam lemak bebasnya akan semakin meningkat. Pada (Gambar 5) dapat dilihat bahwa kedelai varietas Anjasmoro memiliki laju nilai asam lemak bebasnya tidak terjadi peningkatan pada waktu pengusangan 0,15 dan 30 (tidak berbeda nyata menurut uji statistik) dan mulai meningkat asam lemak bebasnya setelah menit ke-30. Pada kedelai varietas Wilis tidak terjadi peningkatan asam lemak bebas pada waktu pengusangan 0 dan 15 menit dan mulai meningkat 
asam lemak bebasnya setelah menit ke-15 (tidak berbeda nyata menurut uji statistik). Jadi untuk menghubungkan asam lemak bebas antara pengusangan dan penyimpanan dilakukan pembagian waktu pengusangan 0 sampai 30 menit menjadi 5 titik (garis putus-putus) pada kedelai varietas Anjasmoro dan waktu pengusangan 0 sampai 15 menit dibagi juga menjadi 5 titik (garis putus-putus) pada kedelai varietas Wilis (Gambar 5) dan diasumsikan setelah penyimpanan alami

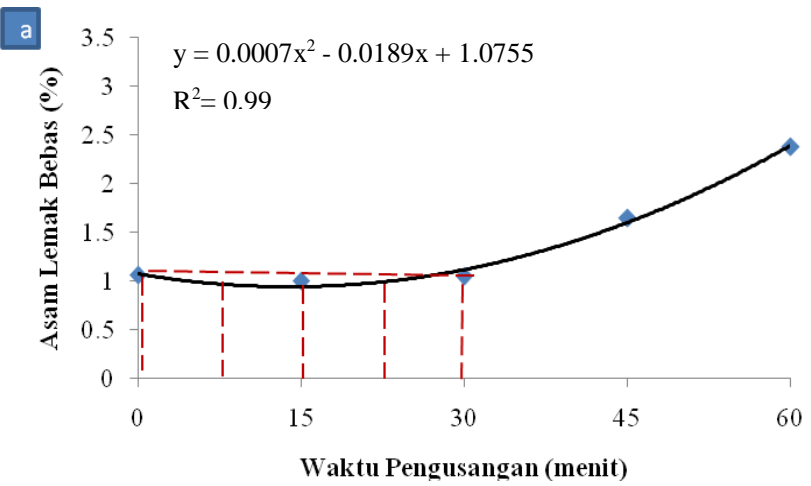

selama 8 minggu terjadi peningkatan asam lemak bebas untuk kedua varietas. Penyimpanan alami selama 0 - 8 minggu memiliki kandungan asam lemak bebas tidak berubah yaitu dikisaran 1.1 $1.2 \%$ untuk Anjasmoro dan dikisaran $0.9-1.0 \%$ untuk Wilis (Gambar 4) dan selama waktu pengusangan $0-30$ menit kandungan asam lemak bebas tidak berubah dikisaran $1.0-1.1 \%$ untuk Anjasmoro dan kisaran $0.9-1.0 \%$ untuk Wilis (Gambar 5).

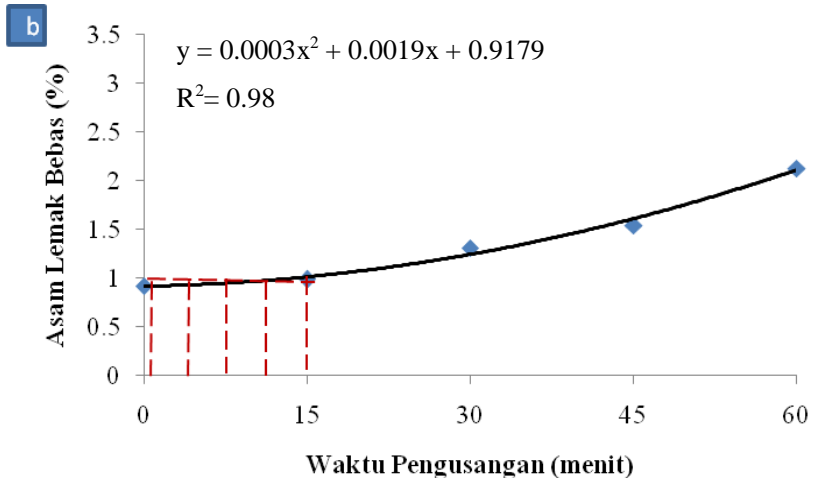

Gambar 5. Garis regresi antara waktu pengusangan dengan asam lemak bebas benih kedelai varietas Anjasmoro (a) dan Wilis (b)

Lemak dan minyak dapat mengalami ketengikan (rancidity), karena dapat terhidrolisis dan teroksidasi bila dibiarkan terlalu lama kontak dengan udara. Reaksi hidrolisis dapat mengakibatkan kerusakan lemak karena terdapat sejumlah air di dalamnya sehingga proses hidrolisis akan menghasilkan asam lemak bebas (Yazid dan Nursanti 2006). Hasil analisis regresi antara asam lemak bebas penyimpanan dengan pengusangan kedelai varietas Anjasmoro dan Wilis menunjukkan bahwa terjadi korelasi yang positif.

Nilai koefisien determinasi $\left(\mathrm{R}^{2}\right)$ antara asam lemak bebas penyimpanan dengan asam lemak bebas pengusangan kedelai varietas

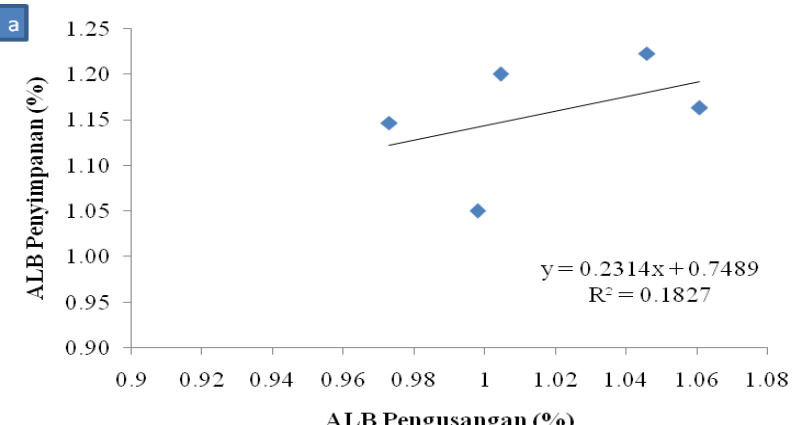

Anjasmoro sebesar 0.18 dan Wilis sebesar 0.60, artinya $18 \%$ dan $60 \%$ dari keragaman asam lemak bebas penyimpanan (y) dapat digambarkan oleh asam lemak bebas pengusangan (x). Nilai koefisien determinasi $\mathrm{R}^{2}<80 \%$ berarti dapat dikatakan bahwa tidak ada kesesuaian nilai asam lemak bebas penyimpanan alami selama 8 minggu dengan pengusangan cepat selama 30 menit (Anjasmoro) dan 15 menit (Wilis) serta memiliki nilai korelasi yang tidak nyata (Gambar 6), untuk menduga kesesuaian peningkatan asam lemak bebas antara penyimpanan dengan pengusangan perlu dilakukan penyimpanan alami lebih dari 8 minggu (diasumsikan setelah penyimpanan selama 8 minggu terjadi peningkatan asam lemak bebas).

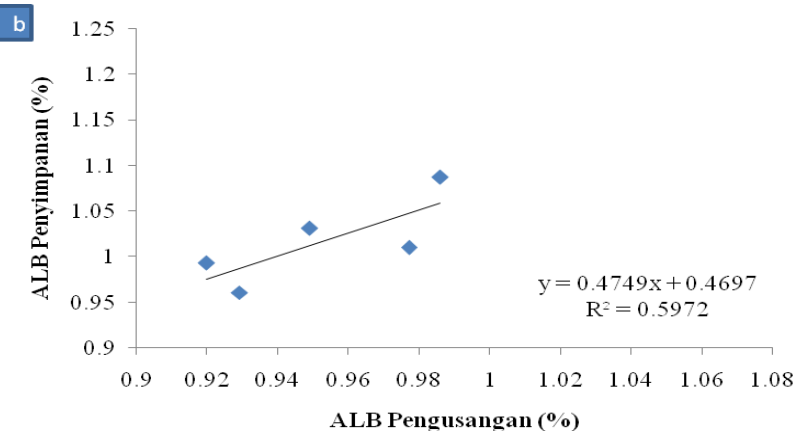

Gambar 6. Garis regresi antara asam lemak bebas penyimpanan dengan asam lemak bebas pengusangan benih kedelai varietas Anjasmoro (a) dan Wilis (b). 
Hubungan antara Penurunan Viabilitas dan Vigor Benih dengan Asam Lemak Bebas

Hubungan antara Daya Berkecambah dengan Asam Lemak Bebas selama Penyimpanan Alami

Hasil analisis regresi antara asam lemak bebas penyimpanan dan daya berkecambah penyimpanan kedelai varietas Anjasmoro dan Wilis menunjukkan bahwa terjadi korelasi yang negatif. Korelasi negatif yang terjadi antara kedua peubah tersebut menunjukkan hubungan yang berbanding terbalik, artinya semakin tinggi nilai asam lemak bebas maka daya berkecambah semakin menurun. Menurut Copeland dan McDonald (2001) salah satu gejala dari

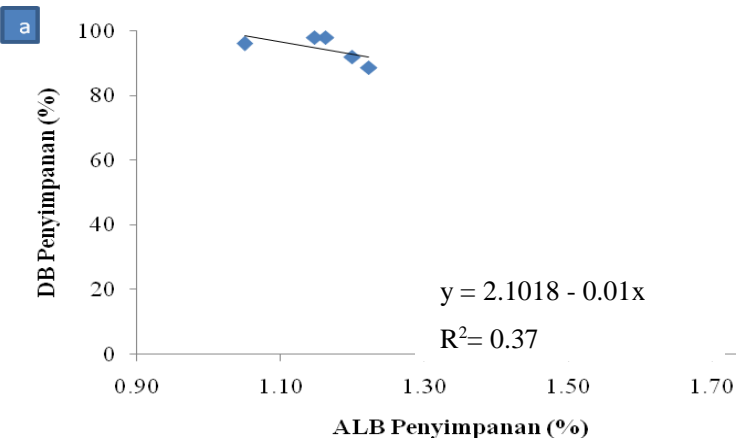

kemunduran benih adalah peningkatan asam lemak bebas, peningkatan asam lemak bebas terjadi karena hidrolisis fosfolipid menyebabkan pelepasan gliserol dan asam lemak, dan reaksi ini dipercepat dengan meningkatnya kelembaban benih. Nilai korelasi (r) varietas Wilis yaitu sebesar 0.89 atau 89\% dan Anjasmoro sebesar 0.60 atau $60 \%$. Nilai $\mathrm{r}$ yang mendekati $1(\mathrm{r} \approx 1)$ menunjukkan hubungan yang sangat erat penyimpanan antara asam lemak bebas dengan daya berkecambah. Nilai korelasi penyimpanan antara asam lemak bebas dan daya berkecambah pada varietas Anjasmoro tidak nyata dan pada varietasWilis menunjukkan nilai korelasi yang nyata (Gambar 7).

Gambar 7. Hubungan antara asam lemak bebas penyimpanan dengan daya berkecambah penyimpanan benih kedelai varietas Anjasmoro (a) dan Wilis (b)

Hubungan Indeks Vigor dengan Asam Lemak Bebas selama Penyimpanan Alami

Hasil analisis regresi antara asam lemak bebas penyimpanan dengan indeks vigor penyimpanan benih kedelai varietas Anjasmoro dan Wilis menunjukkan bahwa terjadi korelasi yang negatif, artinya semakin tinggi nilai asam lemak bebas maka indeks vigor semakin menurun. Nilai korelasi (r) antara asam lemak bebas

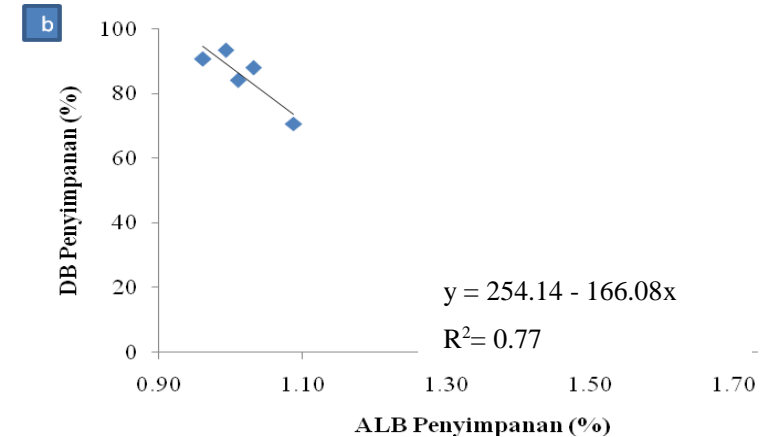

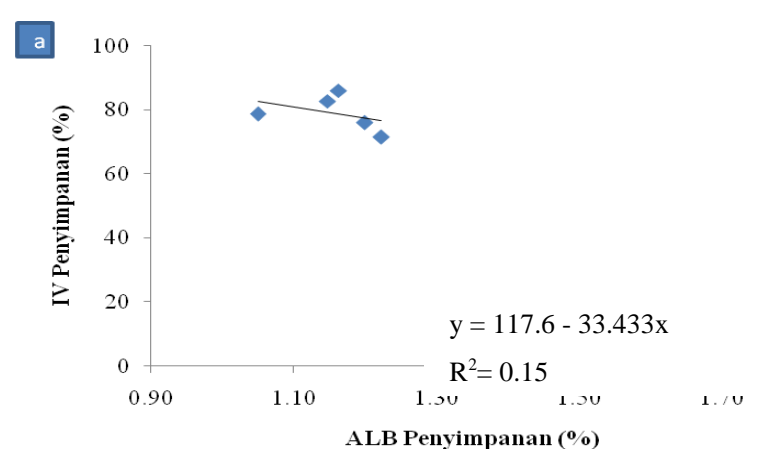

penyimpanan dengan indeks vigor penyimpanan varietas Wilis yaitu sebesar 0.76 dan Anjasmoro sebesar 0.39. Nilai $\mathrm{r}$ yang mendekati $1(\mathrm{r} \approx 1)$ menunjukkan hubungan yang sangat erat antara asam lemak bebas dengan indeks vigor. Nilai korelasi penyimpanan antara asam lemak bebas dan indeks vigor pada varietas Anjasmoro dan Wilis menunjukkan nilai korelasi yang tidak nyata (Gambar 8).

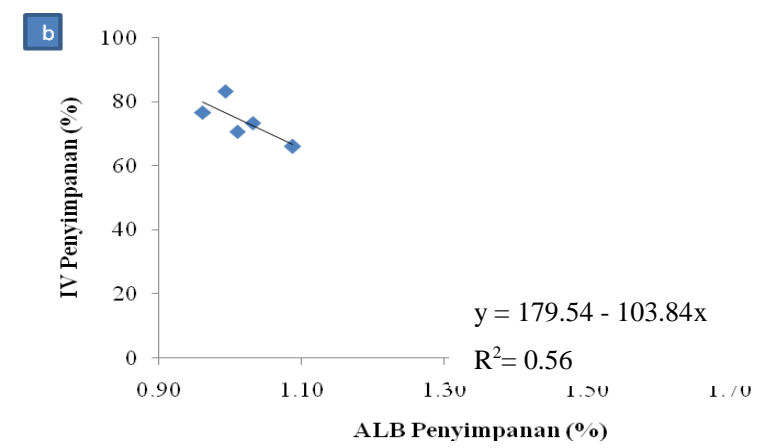

Gambar 8. Hubungan antara asam lemak bebas penyimpanan dan indeks vigor penyimpanan benih kedelai varietas Anjasmoro (a) dan Wilis (b) 
Hubungan antara Daya Berkecambah dengan Asam Lemak Bebas selama Pengusangan

Hasil analisis regresi antara asam lemak bebas pengusangan dan daya berkecambah pengusangan kedelai varietas Anjasmoro dan Wilis menunjukkan bahwa terjadi korelasi yang negatif, artinya semakin tinggi nilai asam lemak bebas maka indeks vigor semakin menurun. Nilai

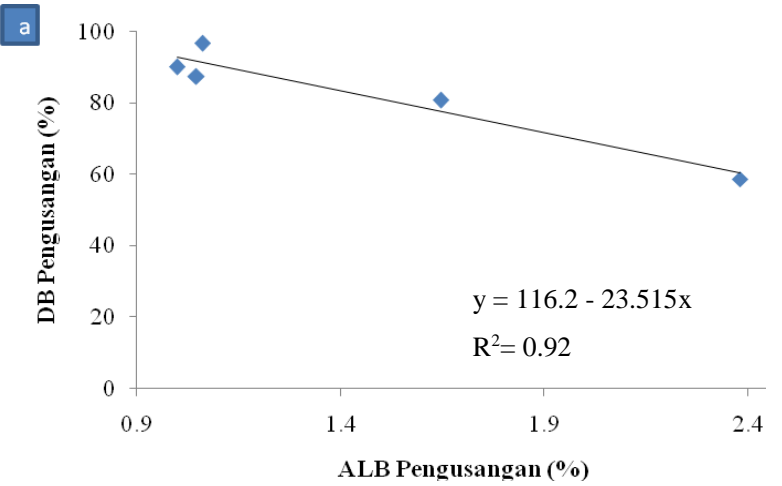

korelasi (r) pada varietas Anjasmoro sebesar 0.96 dan Wilis sebesar 0.99. Nilai $\mathrm{r}$ yang mendekati 1 ( $\mathrm{r}$ $\approx 1$ ) menunjukkan hubungan yang sangat erat antara peubah tersebut. Nilai korelasi pengusangan antara asam lemak bebas dengan daya berkecambah pada varietas Anjasmoro dan Wilis menunjukkan nilai korelasi yang nyata (Gambar 9).

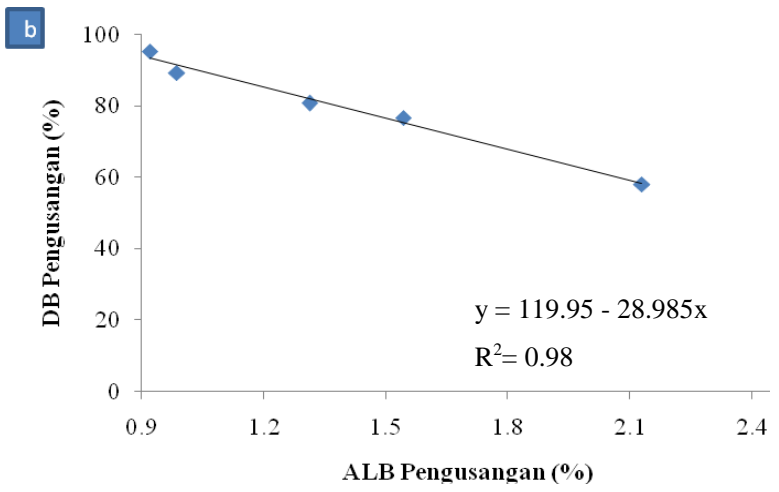

Gambar 9. Hubungan antara asam lemak bebas pengusangan dengan daya berkecambah pengusangan benih kedelai varietas Anjasmoro (a) dan Wilis (b)

Hubungan antara Asam Lemak Bebas dengan Indeks Vigor selama Pengusangan

Hasil analisis regresi antara asam lemak bebas pengusangan dan indeks vigor pengusangan kedelai varietas Anjasmoro dan Wilis menunjukkan bahwa terjadi korelasi yang negatif, artinya semakin tinggi nilai asam lemak bebas maka indeks vigor semakin menurun. Nilai korelasi (r) varietas dan Anjasmoro sebesar 0.96 dan Wilis sebesar 0.98. Nilai $r$ yang mendekati 1 (r $\approx 1$ ) menunjukkan hubungan yang sangat erat antara peubah tersebut. Nilai korelasi pengusangan antara asam lemak bebas dengan indeks vigor pada varietas Anjasmoro dan Wilis menunjukkan nilai korelasi yang nyata (Gambar 10).
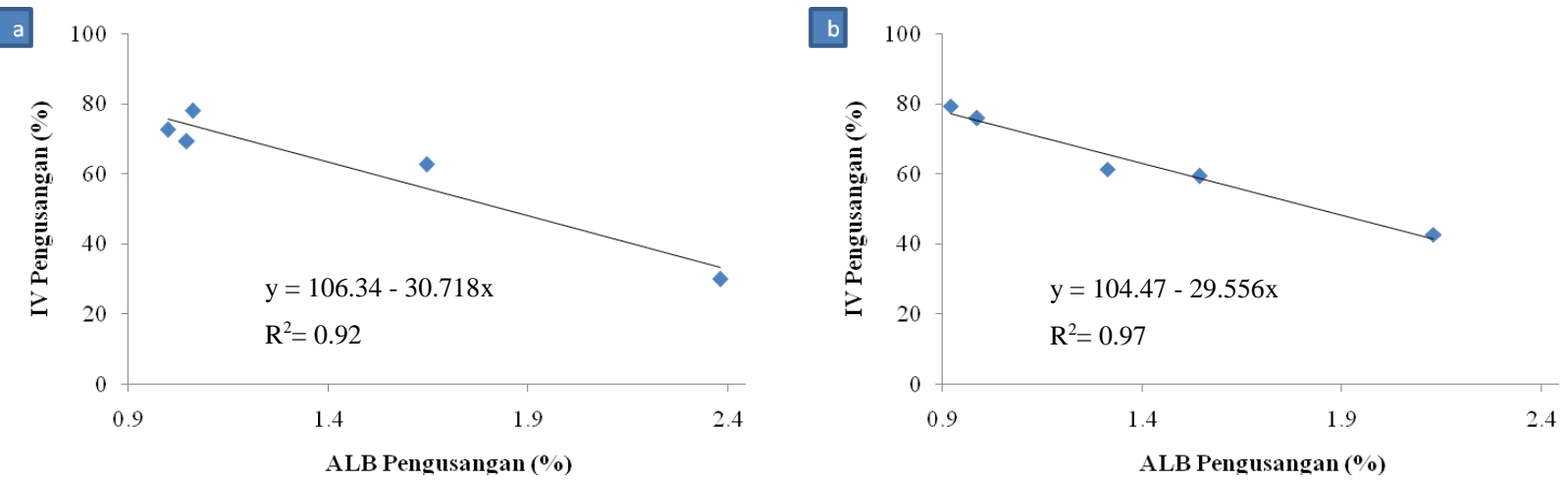

Gambar 10. Hubungan antara asam lemak bebas pengusangan dengan indeks vigor pengusangan benih kedelai varietas Anjasmoro (a) dan Wilis (b)

\section{KESIMPULAN}

Berdasarkan hasil penelitian ini terdapat kesesuaian (korelasi nyata) laju penurunan viabilitas dan vigor, sedangkan pada asam lemak bebas tidak adanya kesesuaian (korelasi tidak nyata) antara penyimpanan alami dengan pengusangan pada kedelai varietas Anjasmoro dan Wilis. Hubungan viabilitas dan vigor dengan asam lemak bebas berkorelasi negatif, artinya semakin tinggi asam lemak bebas maka viabilitas dan vigor semakin rendah. 


\section{DAFTAR PUSTAKA}

[BPS] Badan Pusat Statistik. 2013. Data Kedelai 2011 [internet].[diacu 2013 Januari 10].Tersedia dari: http://www.bps.go.id.

Copeland, L.O., McDonald M.B.. 2001. Principles of Seed Science and Technology $4^{\text {th }}$ Edition. London (USA): Kluwer Academic Publishers.

Imaniar, A. 2012. Pemanfaatan Alat Pengusangan Cepat (APC) untuk Pendugaan Vigor Daya Simpan Benih Kedelai (Glycine max (L.) Merr.) [skripsi]. Bogor (ID): Institut Pertanian Bogor.

Justice, O.L., Bass L.N. 2002. Prinsip dan Praktek Penyimpanan Benih. Rennie R, penerjemah. Jakarta (ID): Raja Grafindo. Terjemah dari: Principles and Practices of Seed Storage.

Ketaren, S. 1986. Pengantar Teknologi Minyak dan Lemak Pangan. Jakarta (ID): UI Press

Kuswanto, H. 2003. Teknologi Pemprosesan, Pengemasan dan Penyimpanan Benih. Yogyakarta (ID): Penerbit Kanisius

Purwanti, S. 2004. Kajian suhu ruang simpan terhadap kualitas benih kedelai hitam dan kedelai kuning. Ilmu Pertanian 11(1): 22 31 .

Sutopo, L. 2004. Teknologi Benih. Jakarta (ID): PT. Raja Grafindo Persada.

Tatipata, A., Yudono P., Purwantoro A., Mangoendidjojo W. 2004. Kajian aspek fisiologi dan biokimia deteriorasi benih kedelai dalam penyimpanan. JIPI. 11(2):76-87.

Yazid, E. Nursanti L. 2006. Penuntun Praktikum Biokimia. Yogyakarta (ID): Penerbit Andi 